\title{
Tripartite Motif-Containing Protein 29
}

National Cancer Institute

\section{Source}

National Cancer Institute. Tripartite Motif-Containing Protein 29. NCI Thesaurus. Code C125263.

Tripartite motif-containing protein 29 (588 aa, $\sim 66 \mathrm{kDa}$ ) is encoded by the human TRIM29 gene. This protein may be involved in the cellular stress response. 